\title{
Miejsce wystandaryzowanego ekstraktu z pomidorów w prewencji pierwotnej schorzeń układu sercowo-naczyniowego. Czy i kiedy stanowi alternatywę dla kwasu acetylosalicylowego? Stanowisko grupy ekspertów
}

\author{
The standardized tomato concentrate therapy in primary cardiovascular \\ disease prevention. Is it an alternative to aspirin and for whom? \\ An expert consensus document
}

\author{
Beata Wożakowska-Kapłon ${ }^{1,2}$, Krzysztof J. Filipiak ${ }^{3}$, Artur Mamcarz ${ }^{4}$, \\ Krzysztof Narkiewicz ${ }^{5}$, Andrzej Tykarski ${ }^{6}$, Krystyna Widecka ${ }^{7}$ \\ ${ }^{1}$ Klinika Kardiologii i Elektroterapii Świętokrzyskiego Centrum Kardiologii w Kielcach \\ ${ }^{2}$ Wydział Nauk o Zdrowiu Uniwersytetu Jana Kochanowskiego w Kielcach \\ ${ }^{3}$ I Katedra i Klinika Kardiologii Warszawskiego Uniwersytetu Medycznego w Warszawie \\ ${ }^{4}$ III Klinika Chorób Wewnętrznych i Kardiologii II Wydziału Lekarskiego Warszawskiego Uniwersytetu Medycznego \\ ${ }^{5}$ Katedra Nadciśnienia Tętniczego i Diabetologii Gdańskiego Uniwersytetu Medycznego \\ ${ }^{6}$ Katedra i Klinika Hipertensjologii, Angiologii i Chorób Wewnętrznych Uniwersytetu Medycznego \\ im. Karola Marcinkowskiego w Poznaniu \\ ${ }^{7}$ Klinika Hipertensjologii i Chorób Wewnętrznych Pomorskiego Uniwersytetu Medycznego w Szczecinie
}

\section{Streszczenie}

Zastosowanie kwasu acetylosalicylowego (ASA) w prewencji pierwotnej schorzeń układu sercowo-naczyniowego (CVD) poddano w wątpliwość z powodu niezadawalającego stosunku korzyści do ryzyka takiego działania. Zastosowanie ASA w tym wskazaniu jest przedmiotem toczących się debat. Doniesienia z piśmiennictwa wskazują na silne antyagregacyjne właściwości wystandaryzowanego ekstraktu z pomidorów (STE). Ekstrakt ten, pełniąc rolę żywności funkcjonalnej bądź suplementu diety, mógłby dzięki swoim właściwościom antyagregacyjnym i przeciwzakrzepowym stać się pomocny w prewencji pierwotnej zdarzeń sercowo-naczyniowych (CV). Zanim zostaną zakończone i opublikowane badania służące ustaleniu ostatecznego miejsca ASA w zapobieganiu incydentom CV, zaprezentowano dokument będący stanowiskiem grupy ekspertów, w którym podsumowano możliwe zastosowanie STE w prewencji pierwotnej CVD w wybranych populacjach osób dorosłych.

Słowa kluczowe: wystandaryzowany ekstrakt z pomidorów, prewencja sercowo-naczyniowa

(Folia Cardiologica 2015; 10, 2: 100-105)

Adres do korespondencji: prof. dr hab. n. med. Beata Wożakowska-Kapłon, I Klinika Kardiologii i Elektroterapii, Świętokrzyskie Centrum Kardiologii, ul. Grunwaldzka 45, 25-736 Kielce, e-mail: bw.kaplon@poczta.onet.pl 


\section{Wstęp}

Schorzenia układu sercowo-naczyniowego (CVD, cardiovascular diseases) nadal stanowią najważniejszą przyczynę zgonów w krajach średnio i wysoko uprzemysłowionych, a koszty społeczne i ekonomiczne tych chorób są bardzo wysokie. Jednym z najistotniejszych czynników patogenetycznych w rozwoju tych schorzeń i prezentacji ich obrazu klinicznego jest wzmożona aktywność prozakrzepowa płytek krwi uczestniczących w patologicznym procesie wykrzepiania związanego z blaszką miażdżycową.

Obok utrzymywania normolipemii, normoglikemii i normotonii, właściwej masy ciała oraz odpowiedniej ilości ruchu, zapobieganie wzmożonej aktywności prozakrzepowej płytek stanowi ważny element postępowania zmierzającego do obniżeniu ryzyka incydentów sercowo-naczyniowych (CV, cardiovascular).

\section{Zmieniająca się rola kwasu acetylo- salicylowego w prewencji pierwotnej zdarzeń sercowo-naczyniowych}

Odkrycie mechanizmów działania kwasu acetylosalicylowego (ASA, acetylsalicylic acid) związanych z zahamowaniem cyklooksygenazy i zmniejszeniem produkcji tromboksanu oraz zwiększeniem stężenia prostacykliny stanowiło podstawę do zastosowania w prewencji zdarzeń CV tego najstarszego, bo zsyntetyzowanego w 1887 roku, leku przeciwpłytkowego. Seria badań klinicznych z zastosowaniem ASA w latach 80. i 90. XX wieku usankcjonowała jego miejsce w terapii CVD. 0 ile jednak nadal niepodważalna jest rola ASA w tak zwanej prewencji wtórnej epizodów CV, tj. u chorych z grupy wysokiego ryzyka CV, po przebytych incydentach naczyniowych (I klasa zaleceń, poziom dowodu A), o tyle jego zastosowanie w prewencji pierwotnej jest znacznie słabiej udokumentowane i stanowi przedmiot wielu kontrowersji [1-4]. U chorych bez uprzedniego epizodu CV w wywiadzie ASA wprawdzie zmniejsza liczbę epizodów pierwszego zawału serca, ale bywa to okupione większą częstością występowania krwawień do światła przewodu pokarmowego oraz krwotoków wewnątrzczaszkowych [5]. Jakkolwiek część ekspertów uważa, że ograniczeniu roli ASA w prewencji pierwotnej epizodów CV towarzyszy potencjalny wzrost roli tego leku w prewencji nowotworów [6], także te drugie - przeciwnowotworowe właściwości ASA bywają podważane [7]. Wąski margines między korzyścią związaną z przyjmowaniem ASA a ryzykiem działań niepożądanych, przede wszystkim krwawień, stanowił podstawę do przedefiniowania roli i znaczenia tego leku w prewencji pierwotnej epizodów CV. Dał temu wyraz dokument Grupy Roboczej ds. Zakrzepicy Europejskiego Towarzystwa Kardiologicznego (Working Group on Thrombosis of European Society of Cardiology) będący oficjalnym stanowiskiem najważniejszego na kontynencie europejskim kardiologicznego towarzystwa naukowego [8]. Swoje stanowisko autorzy dokumentu przedstawili na podstawie metaanalizy danych PubMed przeprowadzonej w 2014 roku [5]. Punktem wyjścia do podjęcia decyzji o zastosowaniu farmakoterapii w prewencji pierwotnej zdarzeń CV powinno być, według autorów tego dokumentu, oszacowanie indywidualnego ryzyka CV opartego w Europie na kalkulacji ESC SCORE (European Society of Cardiology Systematic Coronary Risk Evaluation) lub kartach ryzyka opracowanych przez narodowe towarzystwa naukowe, a w Stanach Zjednoczonych - na kalkulacji ryzyka wystąpienia choroby wieńcowej na podstawie skali Framingham lub nowo opracowanej skali ryzyka dwóch amerykańskich naukowych towarzystw kardiologicznych - American College of Cardiology (ACC) i American Heart Association (AHA) $[1,9,10]$. Skala ESC SCORE służy ocenie 10-letniego ryzyka zgonu z powodu miażdżycopochodnych zdarzeń CV. Jako niskie przyjmuje się ryzyko poniżej 1\%, jako umiarkowane - ryzyko zawarte w przedziale między 1\% a mniej niż 5\%, ryzyko wysokie wynosi między 5\% i więcej a mniej niż 10\%, ryzyko bardzo wysokie natomiast - 10\% lub więcej [1]. Skala Framingham służy do oceny ryzyka wystąpienia incydentów wieńcowych (zawał serca i zgon z przyczyn wieńcowych) w perspektywie 10-letniej, określając ryzyko poniżej 10\% jako niskie, między 10\% a 20\% - jako umiarkowane oraz powyżej 20\% - jako wysokie [9]. Ryzyko wszystkich epizodów CV jest około 3-krotnie wyższe od ryzyka zgonu z przyczyn CV, tj. przy około 5-procentowym ryzyku zgonu występuje 15-procentowe ryzyko incydentu CV, choć u osób w podeszłym wieku ta relacja jest niższa -pierwszy epizod CV częściej może się okazać śmiertelny.

$\mathrm{Na}$ podstawie wieloośrodkowego badania u ponad 100000 uczestników wykazano, że w 10-letniej perspektywie terapia ASA w prewencji pierwotnej wiązała się z obniżeniem wystąpienia 6 przypadków zawału serca u 1000 osób z grupy niskiego ryzyka według skali Framingham. W populacji osób cechujących się umiarkowanym i wysokim ryzykiem redukcja ta obejmowała odpowiednio 19 i 31 epizodów zawału serca na każde 1000 osób przyjmujących ASA [9]. Wadą była zwiększona liczba krwawień neutralizująca korzystne efekty terapii. Ponadto ASA zdawał się również nie wpływać na zmniejszenie ryzyka udaru mózgu. W ostatecznym rozrachunku redukcja liczby zgonów w wyniku przyjmowania profilaktycznie małej dawki ASA wahała się od 0 do 6 przypadków przy 10-letniej terapii u 1000 osób. Ze względu na to, że ryzyko krwawień zwiększało się wraz z ryzykiem CV (22 przypadki krwawień u osób obciążonych wysokim ryzykiem CV/1000 leczonych oraz 4/1000 leczonych w grupie niskiego ryzyka), korzyści z terapii ASA były niemal całkowicie zniesione. Terapia ta prowadziła do znaczącego 22-procentowego wzrostu ryzyka udarów krwotocznych u osób obarczonych wysokim ryzykiem CV [11]. Również wyniki randomizowanych badań 
klinicznych w grupach chorych na cukrzyce nie pozwoliły na potwierdzenie skuteczności terapii ASA w prewencji pierwotnej zdarzeń CV w tej populacji chorych [12]. Zgodnie z obecnie prezentowanym stanowiskiem istnieje bardzo chwiejna równowaga między korzyściami odnoszonymi przez osoby przyjmujące ASA w prewencji pierwotnej CVD a ryzykiem powikłań krwotocznych. Niemniej jednak interpretacja tego stwierdzenia znajduje różny wyraz w stanowiskach ekspertów na obu kontynentach - europejskim i amerykańskim. W wytycznych Europejskiego Towarzystwa Kardiologicznego (ESC, European Society of Cardiology), dotyczących prewencji pierwotnej, ASA nie jest rekomendowany u osób bez jawnej CVD z powodu zwiększonego ryzyka krwawień podczas takiej terapii (III klasa zaleceń, poziom dowodu B), natomiast wytyczne American College of Chest Physicians (ACCP) zawierają sugestię podawania małej, 75-100-miligramowej, dawki ASA u osób powyżej 50. roku życia bez objawowej CVD [10]. W dokumencie ACCP ryzyko CVD u chorych na cukrzycę porównano do cechującego chorych bez cukrzycy [10]. Natomiast amerykańskie naukowe towarzystwa kardiologiczne ACC i AHA oraz Amerykańskie Towarzystwo Diabetologiczne (ADA, American Diabetes Association) zalecają stosowanie ASA w prewencji pierwotnej u chorych na cukrzyce, u których 10-letnie ryzyko zdarzeń CV przekracza 10\% (tj. u mężczyzn w wieku > 50 lat i u kobiet $>60$ lat obciążonych $\geq 1$ czynnikiem ryzyka, takim jak: palenie tytoniu, nadciśnienie tętnicze, dyslipidemia, albuminuria, wywiad przedwczesnej miażdżycy w rodzinie), ale bez zwiększonego ryzyka krwawień z przewodu pokarmowego. Jednocześnie ASA nie zaleca się u chorych na cukrzyce z grupy niskiego ryzyka CV, a jego stosowanie powinno się rozważyć u chorych na cukrzycę cechujących się umiarkowanym ryzykiem incydentów CV (u młodszych pacjentów obciążonych $\geq 1$ czynnikiem ryzyka lub u starszych osób bez czynników ryzyka z 10-letnim ryzykiem zgonu wynoszącym 5-10\%) [12]. Być może, w toczących się właśnie lub czekających na publikację ostatecznych wyników badaniach, między innymi ASPREE (Aspirin in Reducing Events in the Elderly), JPPP (Japanese Primary Prevention Project), ACCEPT-D (Aspirin and Simvastatin Combination for Cardiovascular Events Prevention Trial in Diabetes), zostanie ustalone bardziej jednoznacznie miejsce ASA w prewencji pierwotnej zdarzeń CV [13-16]. Obecnie najwłaściwszym modelem postępowania w populacji osób dorosłych w prewencji pierwotnej CVD nadal pozostaje dokonanie bilansu korzyści i ryzyka zastosowania ASA, z uwzględnieniem liniowego, a nie skokowego zwiększania się ryzyka CV [8]. Stanowisko ekspertów European Society of Cardiology Working Group on Thrombosis zawiera sugestię zastosowania ASA w prewencji pierwotnej u tych chorych, u których ryzyko incydentu CV (zawału serca, udaru mózgu, zgonu CV) w perspektywie 10-letniej jest równe lub wyższe niż $20 \%$, co odpowiada 7-10-procentowemu ryzyku w skali EURO
SCORE. Wykazano zwiększone korzyści z podawania ASA u chorych z przesączaniem kłębuszkowym (eGFR, estimated glomerular filtration rate) obniżonym poniżej $45 \mathrm{ml} / \mathrm{min}$ [17]. W tej grupie stosunek korzyści do ryzyka związanego ze stosowaniem ASA jest najkorzystniejszy. Warunkiem zastosowania ASA w prewencji pierwotnej jest brak wywiadu choroby wrzodowej, krwawienia do światła przewodu pokarmowego oraz nieprzyjmowanie równoczesnie leków zwiększających ryzyko krwawienia (klasa zaleceń Ila, poziom dowodu B). U chorych obciążonych ryzykiem od $10 \%$ do mniej niż 20\% według skali Framingham decyzję należy uzależnić od indywidualnej oceny i preferencji pacjenta. Decyzja odnośnie do włączenia ASA u osób z cukrzycą oraz asymptomatyczną chorobą tętnic obwodowych jest trudna i wydaje się, że korzyści nie przeważają nad ryzykiem [8]. Dodatkowym czynnikiem wpływającym na decyzję o włączeniu ASA do terapii może być ocena przesączania kłębuszkowego (eGFR). Wskazania do zastosowania tego leku w prewencji pierwotnej znacznie się zawęziły; decyzja dotycząca zastosowania ASA w prewencji pierwotnej bywa coraz trudniejsza, a jego zastosowanie w tym wskazaniu powinno być starannie wyważone. Ta swoista detronizacja często zbyt szeroko stosowanego leku bez recepty (OTC, over the counter), jakim jest ASA, stwarza potrzebe poszukiwania i wytypowania substancji, której działaniu antyagregacyjnemu nie towarzyszą niekorzystne działania niepożądane, a jej zastosowaniu mogłyby towarzyszyć pozytywne skutki związane ze zmniejszeniem patologicznej agregacji płytek.

\section{Wystandaryzowany ekstrakt z pomidorów — właściwości biologiczne}

Pomidory są źródłem związków bioaktywnych, z których najważniejsze to polifenole, nukleotydy i izoflawonoidy, a także karotenoidy (likopen, $\beta$-karoten, luteina) i witaminy $[18,19]$. Karotenoidy wykazują działanie antyoksydacyjne; obniżają stężenie oksydowanych cząsteczek cholesterolu frakcji LDL (low-density lipoprotein), prowadząc do zmniejszenia syntezy interleukiny 6 i interleukiny 8, ograniczają reakcje zapalne w świetle naczynia, hamują ekspresję molekuł adhezyjnych na powierzchni komórek oraz migrację komórek do miejsca uszkodzenia [20]. Karotenoidy - poprzez hamowanie ekspresji cytokin zapalnych w tkance tłuszczowej - mogą wpływać na zmniejszenie insulinooporności; ich działanie antyoksydacyjne, przeciwzapalne oraz ochronne na śródbłonek potwierdzono w licznych badaniach [21-23]. Wykazano, że karotenoidy hamują działanie transkrypcyjnego czynnika jądrowego $\mathrm{kB}$ (NF-kB, nuclear factor kB) - głównego mediatora procesów zapalnych w przebiegu miażdżycy [19, 24]. Pomidory są źródłem witamin E i C z grupy antyutleniaczy, kwasu foliowego oraz potasu. Do związków fenolowych zawartych 
w pomidorach należą flawonoidy (flawanony, glikozylowane pochodne naryngeniny) i flawonole (kwercetyna, rutyna, kempferol), kwasy fenolowe i tianiny. Polifenole zawarte w pomidorach zmniejszają ekspresję reniny i konwertazy angiotensyny, decydując między innymi o działaniu hipotensyjnym diety pomidorowej [25]. Do interesujących i niewątpliwie obiecujących zakresów działania ekstraktu z pomidorów należy tłumienie NF-kB, co prowadzi do zmniejszenia syntezy czynnika martwicy nowotworów $\alpha$ (TNF- $\alpha$, tumor necrosis factor-alpha) odpowiedzialnego za adhezję leukocytów, oraz zmniejszenie ekspresji cząstek adhezyjnych - przylegania międzykomórkowego 1 (ICAM-1, intracellular adhesion molecule 1) i cząsteczek przylegania komórek naczyniowych 1 (VCAM-1, vascular cell adhesion molecule 1) [23]. Korzystne działanie związków zawartych w pomidorach potwierdzono po badaniu efektów działania wystandaryzowanego rozpuszczalnego ekstraktu z pomidorów (STE, standarized tomato extract), który jako preparat Fruitflow ${ }^{\circledR}$ został zatwierdzony w 2009 roku przez Europejską Agencję Bezpieczeństwa Żywienia i Żywności (EFSA, European Food Safety Authority) jako środek dietetyczny utrzymujący prawidłową agregację trombocytów [26].

\section{Właściwości antyagregacyjne wystandaryzowanego ekstraktu z pomidorów}

Działanie przeciwagregacyjne STE jest przedmiotem badań już od kilkunastu lat. W badaniu Dutta-Roy i wsp. [27] wykazali hamowanie przez STE aktywacji płytek krwi indukowanej przez adenozynodifosforan (ADP, adenosine diphosphate), trombinę oraz kolagen o około $70 \%$, przy braku wpływu na aktywację płytek zależną od kwasu arachidonowego [26]. Antyagregacyjne działanie STE odbywa się w oparciu o różne szlaki aktywacji płytek. Ekstrakt ten wpływa na zahamowanie procesu agregacji mediowanego przez ADP, tromboksan, kolagen, czynnik von Willebranda, trombinę i mediatory zapalne, blokuje receptor P2Y12 dla ADP, ogranicza proces uwalniania z ziarnistości wewnątrzkomórkowych tromboksanu, ADP, selektyny P i czynnika 4 (PF4, platelet factor 4), zapobiega aktywacji integryny $\alpha_{\text {IIb }} \beta_{\| 1}$ oraz hamuje aktywację receptora glikoproteiny (GP) IIb/IIla. Poprzez blokowanie receptora P2Y1 STE powoduje zmniejszenie aktywności wewnątrzkomórkowej fosfolipazy, co prowadzi do obniżenia stężenia trifosforanu inozytolu, a ostatecznie - do obniżenia stężenia jonów wapnia w komórce. Do mechanizmów działania antyagregacyjnego STE należy również zaliczyć hamowanie procesu wiązania kolagenu z GP VI, a także czynnika von Willebranda z receptorem GP Ib oraz spadek aktywności fosfolipazy C $\beta$ i Cy2 i w konsekwencji zmniejszenia stężenia wewnątrzkomórkowego jonów wapnia i aktywności kinazy białkowej C. Zjawiska te wpływają na kształt trombocytu, skutkując zmianą jego cytoszkieletu, właściwości wewnątrzkomórkowej integryny oraz zapobiegając powstawaniu „pseudopodiów”. Zmiany te mają charakter odwracalny, przy jednoczesnym utrzymywaniu takiego poziomu aktywności płytek, który umożliwia agregację w sytuacji uszkodzenia naczyń $[28,29]$.

W procesie płynnej chromatografii wysokiej rozdzielczości ze STE wydzielono trzy frakcje (tAF, tomato active fractions) - AF1, AF2, AF3 - hamujące agregację płytek w mechanizmie adenozynowym (subfrakcja AF2), zależnym od ADP i kolagenu (subfrakcja AF1) [29]. W skład frakcji AF3 wchodzą związki fenolowe oraz flawonoidy (kwercetyna, kempferol i luteolina) [26]. W kontrolowanym placebo, przeprowadzonym metodą podwójnie ślepej próby, randomizowanym badaniu, obejmującym 90 dorosłych osób w wieku 45-70 lat obojga płci, 3 godziny po podaniu STE uzyskano znaczącą redukcję agregacji płytek krwi, indukowanej przez

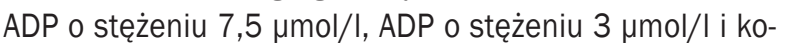
lagen o stężeniu $3 \mathrm{mg} / \mathrm{l}$. Redukcja wynosiła odpowiednio $7,8 \%, 21,3 \%$ i $17,5 \%$. Efekty takie obserwowano u $97 \%$ osób. Natomiast w grupie kontrolnej nie stwierdzono znaczących zmian funkcji płytek krwi [30].

\section{Dla kogo standaryzowany ekstrakt z pomidorów?}

Zmniejszenie roli ASA w prewencji pierwotnej i ograniczenie jego zastosowania u chorych z grupy wysokiego ryzyka CV stwarza lukę, która w wielu sytuacjach może być wypełniona przez STE. Preparat Fruitflow ${ }^{\circledR}$ zawierający STE został zarejestrowany przez EFSA jako środek dietetyczny utrzymujący prawidłową agregację płytek. Zgodnie z powyższą rejestracją docelową populację stanowią dorośli w wieku 35-70 lat [31]. Należy się spodziewać zniesienia warunku stosowania preparatu w podanej grupie wiekowej. Ze względu na swoje wielokierunkowe działanie - antyagregacyjne, hipotensyjne, antyoksydacyjne, antydiabetogenne i ochronne na śródbłonek - STE może być korzystnym suplementem diety osób dorosłych. Szczególne grupy, dla których preparat jest przeznaczony, to:

- osoby z grupy wysokiego i bardzo wysokiego ryzyka CV, u których istnieją nadwrażliwość na ASA, przeciwwskazania do zastosowania tego leku lub wysokie ryzyko powikłań typowych dla ASA;

- chorujący na cukrzycę i/lub nadciśnienie tętnicze bez jawnej choroby CV;

- chorzy z nadciśnieniem tętniczym trudno poddającym się kontroli, z nadciśnieniem i uszkodzeniami narządowymi, którzy z innych przyczyn nie przyjmują ASA;

- osoby z grupy wysokiego ryzyka CV według SCORE niekwalifikujące się jeszcze do terapii przeciwpłytkowej;

- osoby z nadwagą lub otyłością.

Warto pamiętać, że STE może być korzystnym uzupełnieniem terapii antyagregacyjnej w prewencji wtórnej, 


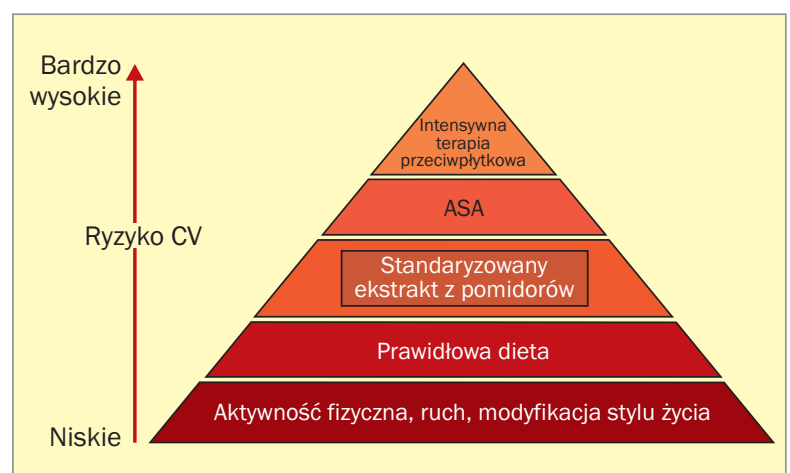

Rycina 1. Propozycja „piramidy modyfikacji agregacji płytek krwi” uwzględniająca aktualne, zawężone wskazania do stosowania kwasu acetylosalicylowego (ASA, acetylsalicylid acid), bardziej intensywnego leczenia przeciwpłytkowego (intensywna terapia przeciwpłytkowa), jak i braku wskazań (niskie ryzyko sercowo-naczyniowe [CV, cardiovascular]); koncepcja autorska piramidy opracowana w gronie ekspertów, analogicznie do „piramidy modyfikacji lipidogramu" zaprezentowanej w II Deklaracji Sopockiej

zwłaszcza w przypadku oporności na stosowany lek przeciwpłytkowy lub niezadawalającą adherencję pacjenta do takiego leczenia, choć miejsce STE w tych właśnie wskazaniach klinicznych wymaga dalszych badań.
Zważywszy na fakt, że ryzyko zdarzeń CV rozwija się w sposób ciągły, a nie skokowo, zarówno osoby z grupy umiarkowanego ryzyka (<5\%), jak i wybrana grupa wysokiego ryzyka (5-6\% wg EURO SCORE) może odnieść korzyści z zastosowania STE. Jego miejsce w piramidzie modyfikacji agregacji ukazuje rycina 1, którą proponują eksperci niniejszego stanowiska [32].

\section{Podsumowanie}

Zgodnie z obecnym stanem wiedzy STE może stanowić alternatywę dla ASA w profilaktyce pierwotnej schorzeń CV w populacji umiarkowanego ryzyka i u wybranych osób wysokiego ryzyka CV oraz cenne uzupełnienie terapii w populacji osób wysokiego i bardzo wysokiego ryzyka przyjmujących ASA. W związku z obserwowanym od kilku lat ograniczaniem wskazań do stosowania ASA w prewencji pierwotnej schorzeń CV, w cukrzycy i w nadciśnieniu tętniczym, STE „wypełnia lukę”, powstałą w wyniku utraty przez wielu pacjentów z podwyższoną aktywnością płytek wskazań do przewlekłego przyjmowania ASA.

\section{Konflikt interesów}

Brak.

\section{Abstract}

The use of acetylsalicylid acid (ASA) in primary cardiovascular (CV) prevention has been abandoned due to the lack of a favorable benefit-to-risk ratio. The indications for ASA use in this setting continue to be a source of major debate. The data indicate that standardized tomato extract (STE) contains very potent anti-platelet components. As a functional food or dietary supplement, STE may have a role in primary prevention of cardiovascular disease (CVD) by reducing platelet activation, which could contribute to a reduction in thrombotic events. While awaiting the results of several ongoing studies with ASA, an expert consensus document for an approach to using STE in primary CV prevention in selected groups of people is presented.

Key words: standardized tomato extract, cardiovascular prevention

(Folia Cardiologica 2015; 10, 2: 100-105)

\section{Piśmiennictwo}

1. Perk J., De Backer G., Gohlke H. i wsp. European Guidelines on cardiovascular disease prevention in clinical practice (version 2012). The Fifth Joint Task Force of the European Society of Cardiology and Other Societies on Cardiovascular Disease Prevention in Clinical. Eur. Heart J. 2012; 33: 1635-1701.

2. Mancia G., Fagard R., Narkiewicz K. i wsp. 2013 ESH/ESC Guidelines for the management of arterial hypertension. The Task Force for the management of arterial hypertension of the European Society of Hypertension (ESH) and of the European Society of Cardiology (ESC). Eur. Heart J. 2013; 34: 2159-2219.
3. Windecker S., Kolh P., Alfonso F. i wsp. 2014 ESC/EACTS Guidelines on myocardial revascularization The Task Force on Myocardial Revascularization of the European Society of Cardiology (ESC) and the European Association for Cardio-Thoracic Surgery (EACTS). Eur. Heart J. 2014; 35: 2541-2619. doi:10.1093/eurheartj/ehu278.

4. Ryden L., Grant P.J., Anker S.D. i wsp. ESC Guidelines on diabetes, pre-diabetes, and cardiovascular diseases developed in collaboration with the EASD. The Task Force on diabetes, pre-diabetes, and cardiovascular diseases of the European Society of Cardiology (ESC) and developed in collaboration with the European Association for the Study of Diabetes (EASD). Eur. Heart J. 2013; 34: 3035-3087. 
5. Baigent C., Blackwell L., Collins R. i wsp. Aspirin in the primary and secondary prevention of vascular disease: collaborative meta-analysis of individual participant data from randomised trials. Lancet 2009; 373: 1849-1860.

6. Brotons C., Benamouzig R., Filipiak K.J. i wsp. A systematic review of aspirin in primary prevention: is it time for a new approach? Am. J. Cardiovasc. Drugs 2015; 15: 113-133.

7. Mills E.J., Wu P., Alberton M. i wsp. Low-dose aspirin and cancer mortality: a meta-analysis of randomized trials. Am. J. Med. 2012; 125: 560-567.

8. Halvorsen S., Andreotti F., ten Berg J.M. i wsp. Aspirin therapy in primary cardiovascular disease prevention. A position paper of the European Society of Cardiology Working Group on Thrombosis. J. Am. Coll. Cardiol. 2014; 64: 319-327.

9. Vandvik P.O., Lincoff A.M., Gore J.M. i wsp. Primary and secondary prevention of cardiovascular disease: Antithrombotic Therapy and Prevention of Thrombosis, 9th edition. American College of Chest Physicians Evidence-Based Clinical Practice Guidelines. Chest 2012; 141: e637S-e668S.

10. Goff D.C. Jr, Lloyd-Jones D.M., Bennett G. i wsp. 2013 ACC/AHA guideline on the assessment of cardiovascular risk: a report of the American College of Cardiology/American Heart Association Task Force on Practice Guidelines. J. Am. Coll. Cardiol. 2014; 63: 2935-2959.

11. Antiplatelet Trialists' Collaboration. Collaborative meta-analysis of randomised trials of antiplatelet therapy for prevention of death, myocardial infarction, and stroke in high risk patients. Br. Med. J. 2002; 324: 71-86.

12. Pignone M., Alberts M.J., Colwell J.A. i wsp. Aspirin for primary prevention of cardiovascular events in people with diabetes: a position statement of the American Diabetes Association, a scientific statement of the American Heart Association, and an expert consensus document of the American College of Cardiology Foundation. Circulation 2010; 121: 2694-2701.

13. Cook N.R., Lee I.M., Zhang S.M. i wsp. Alternate day, low-dose aspirin and cancer risk: long-term observational follow-up of a randomized trial. Ann. Intern. Med. 2013; 159: 77-85.

14. Nelson M., Reid C., Beilin L. i wsp. Rationale for a trial of low-dose aspirin for the primary prevention of major adverse cardiovascular events and vascular dementia in the elderly: Aspirin in Reducing Events in the Elderly (ASPREE). Drugs Aging 2003; 20: 897-903.

15. Teramoto T., Shimada K., Uchiyama S. i wsp. Rationale, design, and baseline data of the Japanese Primary Prevention Project (JPPP) a randomized, open-label, controlled trial of aspirin versus no aspirin in patients with multiple risk factors for vascular events. Am. Heart J. 2010; 159: 361-369.e4. doi: 10.1016/j.ahj.2009.11.030.

16. De Berardis G., Sacco M., Evangelista V. i wsp.; ACCEPT-D Study Group. Aspirin and Simvastatin Combination for Cardiovascular Events Prevention Trial in Diabetes (ACCEPT-D). Trials 2007; 8: 21.

17. Jardine M.J., Ninomiya T., Percovic V. i wsp. Aspirin is beneficial in hypertensive patients with chronic kidney disease: a post-hoc subgroup analysis of a randomized controlled trial. J. Am. Coll. Cardiol. 2010; 56: 956-965.

18. Burton-Freeman B., Talbot J., Park E. i wsp. Protective activity of processed tomato products on postprandial oxidation and inflammation: a clinical trial in healthy weight men and women. Mol. Nutr. Food Res. 2012; 56: 622-631.

19. Miazga A., Kostka-Jeziorny K., Begier-Krasińska B., Tykarski A. Wystandaryzowany ekstrakt z pomidorów (Fruitflow) - czy stanowi alternatywe dla kwasu acetylosalicylowego w profilaktyce pierwotnej chorób sercowo-naczyniowych u pacjentów z nadciśnieniem tętniczym? Nadcisn. Tętn. 2014; 18: 37-42.

20. Shidfar F., Froghifar N., Vafa M. i wsp. The effects of tomato consumption on serum glucose, apolipoprotein B, apolipoprotein A-I, homocysteine and blood pressure in type 2 diabetic patients. Int. J. Food Sci. Nutr. 2011; 62: 289-294.

21. Karppi J., Kurl S., Mäkikallio T.H. i wsp. Serum ß-carotene concentrations and the risk of congestive heart failure in men: a population-based study. Int. J. Cardiol. 2013; 168: 1841-1846.

22. Ciccone M.M., Cortese F., Gesualdo M. i wsp. Dietary intake of carotenoids and their antioxidant and anti-inflammatory effects in cardiovascular care. Mediators Inflamm. 2013; 2013: 782137. doi: 10.1155/2013/782137.

23. Armoza A., Haim Y., Bashiri A. i wsp. Tomato extract and the carotenoids lycopene and lutein improve endothelial function and attenuate inflammatory NF-kB signaling in endothelial cells. J. Hypertens. 2013; 31: 521-529.

24. Friedman M. Anticarcinogenic, cardioprotective, and other health benefits of tomato compounds lycopene, a-tomatine, and tomatidine in pure form and in fresh and processed tomatoes. J. Agric. Food Chem. 2013; 61: 9534-9550.

25. Biswas D., Uddin M., Dizdarevic L.L. i wsp. Inhibition of angiotensin-converting enzyme by aqueous extract of tomato. Eur. J. Nutr. 2014; 53: 1699-1706.

26. Balsam P., Grabowski M. Analiza właściwości przeciwpłytkowych wystandaryzowanego ekstraktu z pomidorów. Choroby Serca Nacz. 2014; 11: 1-6.

27. Dutta-Roy A.K., Crosbie L., Gordon M.J. Effects of tomato extract on human platelet aggregation in vitro. Platelets 2001; 12: 218-227.

28. Palomo I., Fuentes E., Padró T., Badimon L. Platelets and atherogenesis: platelet anti-aggregation activity and endothelial protection from tomatoes (Solanum lycopersicum L.). Exp. Ther. Med. 2012; 3: 577-584.

29. Kubica J., Koziński M., Grześk G. Mechanizmy działania leków przeciwpłytkowych. Folia Cardiol. Excerpta 2009; 1: 10-17.

30. O'Kennedy N., Crosbie L., Whelan S. i wsp. Effects of tomato extract on platelet function: a double-blinded crossover study in healthy humans. Am. J. Clin. Nutr. 2006; 84: 561-569.

31. EFSA Panel on Dietetic Products, Nutrition and Allergies. Scientific Opinion on the modification of the authorisation of a health claim related to water-soluble tomato concentrate and helps to maintain a healthy blood flow and benefits circulation pursuant to Article 13(5) of Regulation (EC) No 1924/2006 following a request in accordance with Article 19 of the Regulation (EC) No 1924/2006 (2009).

32. Wożakowska-Kapłon A., Filipiak K.J., Mamcarz A. i wsp. Aktualne problemy terapii dyslipidemii w Polsce - II Deklaracja Sopocka. Stanowisko grupy ekspertów wsparte przez Sekcję Farmakoterapii Sercowo-Naczyniowej Polskiego Towarzystwa Kardiologicznego. Kardiol. Pol. 2014; 72: 847-853. 